\title{
Mode Exploration of Practical Ability Cultivation of Information Engineering Talent with Integration of Study and Research in University \\ Ling Lijuan ${ }^{1, a}$ \\ ${ }^{1}$ School of Electronic ad Information Engineering,South China University of Technology, Guan gzhou Guangdong 510640, China \\ a690883233@qq.com
}

Keywords: information engineering; practical ability; cultivation mode

\begin{abstract}
With the rapid development of information technology, the request of information engineering talent is more and more urgent. At the present stage, higher education pays more attention to the theory teaching, students' practice ability training is ignored. Aiming at this problem, a practical ability cultivation mode of information engineering talent is proposed based on integration of study and research in university, enterprise production, R \& D and student learning of theoretical knowledge are integrated together, the new teaching mode is formed, and the teaching results achieved by this mode are introduced comprehensively.
\end{abstract}

\section{Introduction}

In the training process of college students in information engineering major, because of the influence of social factors and existing problems of college students themselves, resulting in the employment quality of the graduates decreased year by year. At the same time, the enterprise also cannot recruit the professional talents meet the requirements of the work, the employment of graduates is difficult. The structural contradictions f employment is formed. This contradiction will cause the students decrease the interest in learning, students do not meet the production demand, to employment structural contradictions intensified and enhanced[1].

In order to avoid the contradiction between the demand of students' employment and enterprise recruitment requirements, we need to propose a new training mode, improve the students' ability of practice, so as to meet the needs of manufacturing enterprises[2]. Therefore, a new cultivation mode of information engineering talent is proposed based on integration of study and research in university. The teaching mode combined with enterprise production, R \& D and students learning theory knowledge is elaborated in detail[3]. The achievements of this new teaching mode are introduced comprehensively, and the new mode can improve the students' ability of practice, finally to improve the employment rate of students.

\section{Construction of study and research integration mode}

\section{A.Concept of integration of study and research}

At present, there are many formulations about the integration of industry study and research, but its connotations and meanings are not the same at all. Its relevant understandings are proposed by people from different viewpoints. Some people propose it from macro and micro. Some people propose it from the perspective of historical, economic, social and educational angles. According to the benefit-sharing and risk sharing, the complementary advantages and common development principle are taken into consideration, and the production for the direction of learning is shown as the basis for development. The development of scientific research - products - market is realized with a virtuous cycle, and the research organic integrity is obtained[4-6]. We can see that the integration of industry study and research is a new mode of combination of market economy and the knowledge economy. It is an important part of the national innovation system.

In the teaching process of Information Engineering College Students cultivation, the ways such as basic theory learning, curriculum experiment, project training and school enterprise cooperation 
are taken, and the practice ability of the students is improved. The experimental course of each subject is required for a certain class, according to the professional major, and let the students participate in the enterprise production projects, so as to improve the students' practical ability. The theoretical knowledge and practical ability of students reach a certain level in the foundation, school enterprise joint training is arranged, so that it can truly realize the integration of scientific research, production, and learning theory. Ultimately, it can improve the students' ability of practice.

\section{B.Professional curriculum system of Information Engineering}

In the information engineering major, the college students majoring in integration of teaching mode are constructed, and teaching curriculum setting is the core problem of this mode. The professional includes four parts of general knowledge, such as the based courses, professional knowledge based courses, professional core courses and professional development courses. In view of this practical ability, training courses have the characteristic of $f$ real-time updates, according to the production requirements, and the enterprises change the curriculum at any time. In the cultivation, students can select their own expertise and preferences for the direction of their own interesting. The professional course training is focused on for cultivation. The setting proportion of information engineering university courses can be adjusted dynamically according to the actual conditions and needs. This adjustment shows that the course occupies class can be changed dynamically, and some individual course can be eliminated, updated, and merged.

\section{C.Teachers configuration}

The information industry is a global industry, the industry is very competitive. But in China, because the industry started relatively late, so the overall level is still in the middle position. In this competition environment, the information engineering personnel satisfied the actual production needs should be trained. The strong teacher power should be equipped. In universities, teachers need reasonable arrangement according to the time of admission, teaching mode combine with integration of research and study, the teachers are arranged to different positions for improvement of ability, so the teachers play a leading role. College teachers need to include school full-time teachers, trainers, and regular exchange of teachers college enterprise, and the school full-time teachers are arranged into the enterprise for satisfying the practical training demands. The arrangement of enterprise training teacher for learning theory to improve the theoretical level, so as to improve the level of construction of a professor, teaching practice platform is constructed. Finally, the formation of a strong professional knowledge is obtained. It understands the industry needs, the professional knowledge stays in line with the actual needs of production, and the teachers have rich teaching experience with professional, teachers' strength is enhanced.

\section{D.Project training}

Training mode of information engineering talent in university is the core content of project training. Through the project practice, it can make the students deep into practical projects, and greatly improve the practice ability of students.

Project training refers to the process of project implementation, and it guides students to learn content for project implementation, according to the encountered difficulties of project development, the theory learning is carried out. In the project of training process, need the full-time teachers participate in project for guiding the students in college. Through the project practice, to improve the students' comprehensive practical ability, ability of engineering design is improved. In the training process, teachers not only need to be responsible for the knowledge of the professor, but also need of help urge the students to finish the project development. "Project training laboratory" has become an important platform of practice and information engineering talent training, the students are taken as the main project development personnel, teachers are taken as the project to guide the development of personnel, on the basis of this concept, cooperation between the 
information engineering specialty students and teachers are constructed, so as to improve the students' practical level.

In order to manage the training laboratory project better, improve the students in the project training, the team spirit should be improved in the process, and university needs to carry on the project training management and evaluation. The qualified rate for training students, the progress of project development, and project statistics are taken into consideration. Organize various forms of project development competition, mobilize the enthusiasm of students in project development, and improve the students' ability of project development.

\section{E.R \& D capability cultivation}

The cultivation of the information engineering personnel must conform to the actual demand of information industry development. Therefore, actual project demand of information engineering is taken as the core, teaching students who are majoring in information engineering. Therefore, in the information engineering university personnel training process, the school and enterprise union is necessary, make the teaching process more flexible, more able to meet the needs of the market, and ultimately improve the students' practical ability and the ability of research and development. In the project of training process, it has made the student project development ability can be improved effectively. However, some of the information engineering enterprise in related field need not only simple project executive, but also includes some professional R \& D personnel, which requires information engineering college class teaching pay attention to the long-term training of students' research ability, so as to cater to the needs of the market.

\section{F.Joint training of college and enterprise}

In the relevant enterprise information engineering field, the typical modern society has their own training department, the department has advanced equipment and perfect management system, and they have rich practical experience of the trainers. In the information engineering specialty of universities and colleges, during the senior term, assign students to conduct training for different enterprises, enabling students to deep into the $\mathrm{R} \& \mathrm{D}$ and production enterprises.

Enterprises are also very accept this teaching method, The enterprise training mode can increase the income of the enterprise, and found suitable students for their own business talents in a large number of training students. Through this joint training of schools and enterprises, the students' practical ability is improved, and improves the employment rate of students. In the process of enterprise training students, according to the capacity of a complete evaluation system of students, each direction of research is determined, the research is carried out in the training process, so it contains the occupation literacy training, theoretical knowledge training and project practice training stage. According to the different stages of enterprise training, the evaluation can be divided into three parts of the following:

(1) Occupation literacy training take thirty points(written examination accounted for $40 \%$, experiments accounted for $60 \%$ ), the scores are more than 18 , it is taken as qualified,.

(2) The theoretical knowledge training takes thirty points (written examination which accounted for $40 \%$, accounted for $60 \%$ ), when the scores are more than 18 , it is qualified.

(3) The project practice training takes forty points, written accounts for $20 \%$, experiment accounted for $60 \%$, and more than 24 points are referred as qualified.

After 8-12 weeks of enterprise training, examination scores are compared between the good students, it can stay in training units continue to work, and then you can also choose to enter other businesses.

\section{Example analysis}

The Electronics and Information Institute of South China University of Technology is taken as an example, the information engineering of the college establishes a research and the practice of integrated ability training mode. School of electronic and information engineering has constructed 
experimental teaching center, engineering training laboratory. At the same time, it will also work with the enterprises set up joint project research and development center. In addition, the Electronics and Information Institute establishes some SRP projects, the cooperation is constructed between enterprises, such as DESAY group and other large enterprises electronic design competition, it can enhance the ability to solve practical engineering problems. Training mode is formed to integrate the practice ability and the practice experience, greatly improving the students' ability of practice, so as to make the graduates more meet the needs of enterprises. And ultimately improve the students' employment quality. The quality of employment is significantly improved.

\section{Conclusions}

Practice research integration ability training mode is a kind of enterprise production and R \& D emerged into the daily teaching mode. In the teaching process, to enable students to learn the knowledge according to actual production requirement, the ultimate realization of learning is obtained. And in the corporate training, this mode enables students to enter the "pre employment" state, to improve the students' practical ability and occupation accomplishment. In the process of information engineering talent training, use of integration of the teaching mode, it will have a certain degree of adjustment to the faculty. The faculty, curriculum, curriculum content, project training content are adjusted to a certain degree, it will keep in line with the needs of enterprises, the overall quality of students has been improved, the project development capabilities will continue to increase.

The practice ability training mode of integration of research is helpful to improve students' ability to practice teaching mode. Many colleges and universities have access to practice good results, and information engineering students' employment quality is improved. Because our school integration of practice ability training mode is still in the primary stage, all aspects of the management is not perfect, it need further adjustment. The efforts from schools, enterprises, students and other aspects are paid, education reform is deepen, the school teach practice ability level is improved, and ability of employment rate and the quality of employment is improved finally.

Supported by the Graduate Education Innovation Project of Guangdong Province

( No. 2013JGXM-MS05 ), and the Higher Education Research Fund of South China University o f Technology (No. GJ2013009)

\section{References}

[1] WU Lan. Based on The Variety Constraint Model of Remote Education Database Quer y Optimization Algorithm[J]. Bulletin of Science and Technolog, 2013,1(29):155-160.

[2] YANG Jian. Application of Cloud Computing in Modern Logistics[J]. Logistics Technol ogy. 2012, 31(11): 415-416, 449.

[3] DENG Jing-sheng. The new view about reform of the method of pre-service teacher ed ucation practice under the background of new curriculum[J]. CAREER HORIZON, 2012, 8(9): 81-83.

[4] Chen Chaowen. Discussions on the Reform of Tanching Practice for Computer Science Majors[J]. Journal of Nanning Teachers College, 2005, 22(3):75-77.

[5] HUANG Chao, NAN Jian - guo. Simulation Analysis of Communication Optimization Algorithm of FC Fibre Channel[J]. Computer Simulation, 2013, 30(8): 194-197.

[6] SUN Zhen, WANG Zhao-xia, BAI Ming, et al. Image Inpainting Method Based on Self -organizing Maps and K-means Clustering[J]. Science Technology and Engineering, 2012; 12(8): 1790-1794. 